\title{
Enhancing Yield and Water Productivity of Wheat (Triticum aestivum) Through Sowing Methods and Irrigation Schedules under Light Textured Soil of Western Uttar Pradesh, India
}

\author{
Vikrant Singh $^{1 *}$, R.K. Naresh ${ }^{1}$, Ravindra Kumar ${ }^{2}$, Adesh Singh ${ }^{1}$, U. P. Shahi ${ }^{3}$, \\ Vivak Kumar ${ }^{4}$ and N.S. Rana ${ }^{1}$ \\ ${ }^{1}$ Department of Agronomy, Sardar Vallabhbhai Patel University of Agriculture and Technology, \\ Meerut-250110, U.P., India \\ ${ }^{2}$ Department of Cell Biology, Sardar Vallabhbhai Patel University of Agriculture and \\ Technology, Meerut-250110, U.P., India \\ ${ }^{3}$ Department of Soil Science, Sardar Vallabhbhai Patel University of Agriculture and \\ Technology, Meerut-250110, U.P., India \\ ${ }^{4}$ Department of Agricultural Engineering, Sardar Vallabhbhai Patel University of Agriculture \\ and Technology, Meerut-250110, U.P., India
}

*Corresponding author

\section{Keywords}

Wheat, Tillage systems, Irrigation levels, Growth,

Productivity, Profitability.

Article Info

Accepted:

12 March 2017

Available Online:

10 April 2017

\section{A B S T R A C T}

A field experiment was conducted at Crop Research Centre of Sardar Vallabhbhai Patel University of Agriculture \&Technology, Meerut (U.P.) during Rabi season of 2014-15 and 2015-16. To evaluate the effect of different tillage practices and irrigation scheduling in wheat (Triticum aestivum L.) under light textured soil of western Uttar Pradesh. Five tillage crop establishment methods, viz. zero tillage (ZT)- $\mathrm{T}_{1}$, reduced tillage (RT)- $\mathrm{T}_{2}$, rotavator tillage $(\mathrm{ROT})-\mathrm{T}_{3}$, furrow irrigated raised bed tillage (FIRB)- $\mathrm{T}_{4}$, conventional tillage $(\mathrm{ZT})-\mathrm{T}_{5}$, were kept in main plots and five irrigation scheduling viz. Irrigation at CRI- $\mathrm{I}_{1}, \mathrm{CRI}+50 \mathrm{~mm} \mathrm{CPE}-\mathrm{I}_{2}, \mathrm{CRI}+100 \mathrm{~mm} \mathrm{CPE}-\mathrm{I}_{3}, \mathrm{CRI}+150 \mathrm{~mm} \mathrm{CPE}-\mathrm{I}_{4}$ and CRI+200 $\mathrm{mm}$ CPE- $\mathrm{I}_{5}$ were allotted to sub-plots in a split-plot design and replicated thrice. The result showed that productive tiller's $\mathrm{m}^{-2}$, number of grain spike ${ }^{-1}$ and test weight were significantly higher with wheat sown on wide raised beds than all other tillage practices except zero tillage plots. Similarly furrow irrigated raised beds increased the mean grain yield of wheat significantly over rest of the plots and grain yield increased by and $38.4 \%$ over $\mathrm{I}_{1}$ and $6.4 \%$ over $\mathrm{I}_{4}$ irrigation schedule. Treatments under zero tillage $\left(\mathrm{T}_{1}\right)$ had about $3.4 \%$ higher average soil bulk density than $\mathrm{T}_{4}$ plots and $\mathrm{T}_{4}$ FIRB also recorded highest infiltration rate; reduced tillage, and FIRB recorded significantly lower soil penetration resistance as compared to zero and rotavator tillage treatments. The maximum gross income was significantly higher in wide raised beds plots. Similarly the highest mean net profit (Rs $45906 \mathrm{ha}^{-1}$ ) with mean B: C ratio of 1.55 was recorded with the application of irrigations at $\mathrm{CRI}+100 \mathrm{~mm} \mathrm{CPE}$ in wheat crop. The results suggest that $\mathrm{ZT}$ with irrigations at $\mathrm{CRI}+100 \mathrm{~mm} \mathrm{CPE}$ and FIRB irrigations at CRI+50mm CPE were optimum and sustainable strategy to achieve higher yield and also to improve water productivity and profitability on light textured soil of western Uttar Pradesh. 


\section{Introduction}

Wheat (Triticum aestivum L), a major cereal crop is being cultivated in the country. The main reasons for its low productivity are poor crop establishment and improper scheduling of irrigation. Amongst the other agronomic practices proper crop establishment practices may considerably increase the production of wheat to some extent. It is also well know fact that water management is one of the major factors responsible for achieving better harvest in crop production. Both crop establishment practices and irrigation schedule are major causes of yield reduction in wheat, which also affect its water productivity and profitability. Bread wheat (Triticum aestivum L.) is the most widely grown and consumed food crop and is the staple food for $35 \%$ of the world population (Rajaram et al., 2007). The irrigated wheat systems contribute over $40 \%$ of wheat production in the developing world (Rajaram et al., 2007).To meet the growing wheat demand, the global production need an 1.6 to $2.6 \%$ annual growth rate, which can be mainly achieved through improvement in input use efficiency (Rajaram et al., 2007). However, under the current production practices, crop productivity and input use efficiency has decreased /stagnated. In the Indo- Gangetic Plains (IGP), ground water is being depleted 13 to $17 \mathrm{~km}^{3} \cdot \mathrm{yr}^{-1}$ (Rodell et al., 2009) coupled with diminishing factor productivity (Ladha et al., 2003), an accelerated growth in crop productivity needs an enhanced resource use efficiency to meet the future wheat demand in the region. The improvement of input use efficiency in wheat cropping systems can be achieved through two main strategies: by adopting precise and more efficient crop management practices (Reynolds et al., 2004).

Tillage plays a key role in changing the hydro-physical properties. Blanco-Canqui and Lal (2007) indicated that water infiltration and runoff are closely related to the physical condition of the upper layer of the soil profile. Shaver et al., (2002) reported that physical properties such as bulk density and porosity near the soil surface are most important for dictating the infiltration characteristics of the soil at the soil-water interface. Naresh et al., (2013) however, found that infiltration was more closely related to pore continuity than to porosity. Field experiments with zero tillage in wheat at several locations in the IndoGangetic plains have shown encouraging results (Jat et al., 2005; Saharawat et al., 2010). Farmers have found direct drilling of wheat into post rice systems without tillage feasible and beneficial at several locations. Wheat yields with zero tillage are either equal or even better than those obtained with conventional tillage because of timely planting of wheat, efficient use of fertilizers and weed control. In addition, zero tillage is fuel and energy efficient but also reduces greenhouse gas emissions (Hill et al., 1991). Zero tillage systems conserve the land resource and are cost effective and efficient. Moreover, this tillage system also avoids challenges with clod formation.

Raised bed planting systems has been used since time immemorial by farmers in many parts of the world (Govaerts et al., 2007).Their application has traditionally been associated with water management issues, to reduce the adverse impact of excess water on crop production or to irrigate crops in semiarid and arid regions (Sayre, 2004) where water productivity is comparatively low. A widely used application of raised beds in many semi-arid and arid areas is to plant crops on the edges of beds or ridges that are formed between furrows that carry irrigation water. Monsefia et al., (2016) found that furrow-irrigated raised-bed planting system (FIRBS) is a form of tillage wherein sowing is done on raised-beds. This optimizes tillage operation, saves water, reduces lodging, and 
ensures better fertilizer use. Ladha et al., (2009) found no-tillage and reduced tillage systems were most profitable due to saving of labour, time, water and energy costs. There are several reports showing savings in irrigation water, labour and production costs, and higher net economic returns in no tillage and reduced tillage compared with conventional tillage systems. Thus, proper irrigation strategies are essential for wheat to optimize water use without sacrificing the yield. This study investigated the effects of number and time of irrigation on growth and yield attributes, yield, and water productivity of four tillage crop establishment methods compared with conventional method with an objective of defining an appropriate irrigation schedule matching with particular planting technique.

Proper scheduling of irrigation (amount and timing) to crops is an important component of water saving technologies. There are numerous ways to schedule irrigations and estimate the required depth of water application (Campbell and Campbell, 1982). All irrigation scheduling methods consist of monitoring indicators that determine the need for irrigation. Prihar et al., (1974) suggested a simple approach based on meteorological parameters to schedule irrigation to crops based on the ratio between fixed depth (75 $\mathrm{mm}$ ) of irrigation water (IW) and net cumulative pan evaporation since previous irrigation (PAN-E minus rainfall). Irrigating wheat using this approach (IW/PAN-E $=0.9)$ saves 2 irrigation compared to 5-6 irrigations at fixed growth stages without any yield loss (Prihar and Sandhu, 1987). To increase availability of irrigation water there is need to quantify the irrigation water by using improved irrigation method and proper scheduling of irrigation to obtain more yield and economic returns. The objective of this research was to evaluate the effects of irrigation schedules on wheat yield, water productivity, properties of soil and profitability under different sowing methods.

\section{Materials and Methods}

\section{Experimental site}

The field experiment was established in 2014 at Sardar Vallabhbhai Patel University of Agriculture and Technology, Meerut, U.P., India research farm (290 04', N latitude and770 42' ' $E$ longitude a height of $237 \mathrm{~m}$ above mean sea level). The region has a semiarid sub-tropical climate with an average annual temperature of $16.8^{\circ} \mathrm{C}$. The hottest months are May and June, when the maximum temperature reaches 45 to $46^{\circ} \mathrm{C}$, whereas, during December and January, the coldest months of the year, the temperature often drops below $5^{\circ} \mathrm{C}$. The average annual rainfall is $765 \mathrm{~mm}, 75$ to $80 \%$ of which is received through the Northwest monsoon during July to September. The predominant soil at the experimental site is classified as Typic Ustochrept. Soil samples for $0-20 \mathrm{~cm}$ depth at the site were collected and tested prior to applying treatments and the basic properties were non-saline (EC $0.42 \mathrm{dS} \mathrm{m}^{-1}$ ) but mild alkaline in reaction $(\mathrm{pH} 7.98)$. The soil initially had $4.1 \mathrm{~g} \mathrm{~kg}^{-1}$ of SOC and $1.29 \mathrm{~g}$ $\mathrm{kg}^{-1}$ of total $\mathrm{N}(\mathrm{TN}), 1.23 \mathrm{~g} \mathrm{~kg}^{-1}$ of total phosphorus, $17.63 \mathrm{~g} \mathrm{~kg}^{-1}$ of total potassium, $224 \mathrm{mg} \mathrm{kg}^{-1}$ of available $\mathrm{N}, 4.0 \mathrm{mg} \mathrm{kg}^{-1}$ of available phosphorus, and $97 \mathrm{mg} \mathrm{kg}^{-1}$ of available potassium.

\section{Treatment details}

A detailed description of crop establishment methods are necessary to compare the influence of land configuration practices on environmental performance (Derpsch et al., 2014).The experiment was laid down in split plot design with three replications, keeping planting techniques as main plot and irrigation scheduling as sub-plots. The 
treatments comprised of five main plots; 1 ) planting techniques viz. zero tillage (ZT)- $\mathrm{T}_{1}$, reduced tillage (RT)- $\mathrm{T}_{2}$, rotavator tillage (ROT)- $\mathrm{T}_{3}$, furrow irrigated raised bed tillage (FIRB)- $\mathrm{T}_{4}$, conventional tillage (ZT)- $\mathrm{T}_{5}$, and five sub-main plots were of irrigation scheduling viz. Irrigation at CRI- $\mathrm{I}_{1}, \mathrm{CRI}+50$ $\mathrm{mm} \mathrm{CPE}-\mathrm{I}_{2}, \mathrm{CRI}+100 \mathrm{~mm} \mathrm{CPE}-\mathrm{I}_{3}, \mathrm{CRI}+$ $150 \mathrm{~mm} \mathrm{CPE}-\mathrm{I}_{4}$ and CRI $+200 \mathrm{~mm} \mathrm{CPE}-\mathrm{I}_{5}$.

\section{Cultural practices}

Zero-till (ZT) system of planting crops with minimum of soil disturbance was performed with Zero-till seed drill. By this equipment, seeds were placed directly into narrow slits 2 $4 \mathrm{~cm}$ wide and 4-7 $\mathrm{cm}$ deep made with a drill fitted with chisel, inverted T" without land preparation. In reduced tillage (RT) perse still exists, but numbers of preparatory tillage operations were reduced significantly. One ploughing with harrow followed by one round of cultivator was used before sowing with seed drill in rows $20 \mathrm{~cm}$ apart. Under rotavator tillage (ROT) soil was disturbed prior to planting by rotavator to prepare the seedbed and wheat was sown in zigzag way using a Roto-till-ferti seed drill. In case of furrow irrigated raised bed tillage (FIRB) soil was tilled by harrowing and ploughings followed by one field levelling with a wooden plank, and raised beds were made using a tractor-drawn multi crop raised bed planter with inclined plate seed metering devices. The dimension of the beds was $40 \mathrm{~cm}$ wide (top of the bed) x $12 \mathrm{~cm}$ height $\times 30 \mathrm{~cm}$ furrow width (at top) and the spacing from centre of the furrow to another centre of the furrow was kept at $70 \mathrm{~cm}$. Three rows of wheat were sown on each raised bed keeping one row at centre and remaining two at both edges. Following the conventional practice (CT) of two harrowing, three ploughing (using a cultivator) thereafter planking (using a wooden plank) that followed pre-sowing irrigation and wheat was seeded in rows 20 cm apart using a seed drill with a dryfertilizer attachment.

\section{Fertilizers application and crop management}

In order to raise ideal crop recommended dose of $\mathrm{N}$ : P: K (150:60:40) was applied in all treatments. The recommended basal dose of $\mathrm{N}$ @ $75 \mathrm{~kg} \mathrm{ha}^{-1}, \mathrm{P}_{2} \mathrm{O}_{5} @ 60 \mathrm{~kg} \mathrm{ha}^{-1}$ and $\mathrm{K}_{2} \mathrm{O}$ @ $40 \mathrm{~kg} \mathrm{ha}^{-1}$ was applied uniformly as a basal dose using seed-cum-fertilizer drill at the time of seeding operation. $\mathrm{N}$ : P: K were applied through combination of Urea, DAP and MOP. Rest dose of $\mathrm{N}$ in form of urea was applied in two equal split doses at 25 and 55 DAS synchronizing with irrigation application. Wheat PBW-550 was sown as recommended timely sown variety for North-West-Plain Zone@100 kg ha ${ }^{-1}$. For controlling weeds, pre-sowing spray was done manually by knap sack sprayer. Glyphosate a non selective presowing herbicide was applied @ $1.0 \mathrm{~kg}$ a.i. $\mathrm{ha}^{-1}$ and post emergence selective herbicide Sulfosulfuron $75 \%$ was applied @ 25 a.i.g ha $^{-1}+$ Metasulfuron $10 \% @ 4$ a.i. g ha ${ }^{-1}$ used after 25 DAS with 4201 of water during both years of investigation. Harvesting was done manually by improved sickle. The border of individual plot was harvested and separated as a general crop. Thereafter the total biomass production of individual net plot $\left(14.4 \mathrm{~m}^{2}\right)$ was harvested and left in the field for 3 days under sun drying so as to keep the grain moisture level at optimum i.e. $12 \%$.

\section{Water productivity}

Soil moisture content was measured at seeding, before and after irrigation on the top of the ridge and furrow in furrow irrigated raised bed planting system and between the two rows in flat planting. Consumptive use was worked out from the loss in soil moisture, effective rainfall and potential evapotranspiration for 2 days following irrigation. 
WUE was calculated by the following formula:

WUE $=\frac{\mathrm{Y}}{\mathrm{U}}$ Where: $\quad \mathrm{Y}=$ crop yield $\left(\mathrm{kg} \mathrm{ha}^{-}\right.$ $\left.{ }^{1}\right) ; \mathrm{U}=$ seasonal consumptive use $(\mathrm{cm})$

This study was to evaluate the water productivity of wheat. The unit plot size was $26 \mathrm{~m}^{2}$. Before applying irrigation the moisture content of the soil was measured using oven dry method and the amount of irrigation requirement was calculated. Irrigation schedule was done on CPE data observed on daily basis.

\section{Soil sampling and analysis}

The bulk density of soil was determined on volume and weight basis. Bulk density of soil was calculated by the following formula and expressed in mega gram per cubic meter $\left(\mathrm{Mg} / \mathrm{m}^{3}\right)$ (Piper, 1966). The infiltration rate of water through soil was measured using a double-ring infiltrometer from two spots within each plot. Core index was measured to obtain soil penetration resistance (SPR) in the $0-0.05 ; 0.05-0.15$ and $0.15-0.30 \mathrm{~m}$ soil depths. After recording the SPR value, soil samples from the same layer was collected with the help of a tube auger for determining gravimetric moisture content.

\section{Yield and yield attributes determination}

Yield attributes from shoots bearing spike at the time of harvesting was recorded by using a quadrate of one square meter in each plot. However, in case of FIRB one meter row length was chosen for recording yield attributes. After harvesting, the wheat crop was sun dried and then weight of net plot area harvested was recorded in $\mathrm{kg}$ and expressed as $\mathrm{q} \mathrm{ha} \mathrm{h}^{-1}$. The produce from net plot was threshed separately by plot thresher and grain yield was recorded. Straw yield was computed from net area by subtracting the grain yield from the biological yield and later converted into $\mathrm{qha}^{-1}$.

\section{Statistical analysis}

All the data recorded during the course of investigation were analyzed by analysis of variance technique (ANOVA) using the Statistical Analysis System (SAS Institute, 2001). The comparison of treatment means were made by the least significant difference $(\mathrm{LSD})$ at $5 \%$ probability $(\mathrm{p}=0.05)$.

\section{Results and Discussion}

\section{Yield attributes and yield performance}

Data on various yields attributing characters viz. productive tiller's $\mathrm{m}^{-2}$, number of grains spike-1, and test weight, as influenced by tillage-cum-crop establishment methods and different irrigation schedules are presented in (Table 1) revealed that $T_{4}$ FIRB tillage crop establishment practices influenced significantly more productive tiller's followed by $\mathrm{ZT}>\mathrm{RT}>\mathrm{ROT}>\mathrm{CT}$. The number of grains spike $^{-1}$, and test weight higher with T4 FIRB as compare to remaining treatments. However, they followed closely by ZT thereafter $\mathrm{RT}>\mathrm{ROT}>\mathrm{CT}$, respectively. Irrigation scheduling had a significant effect on yield attributes. Treatment $\mathrm{I}_{1}$, which received irrigation only at CRI, had significantly $(\mathrm{p}<0.05)$ lower productive tillers, fewer grains spike ${ }^{-1}$ and lower test weight than all the other treatments. The lower count was due to no moisture supply after CRI stage. Treatment $I_{5}$ had significantly lower productive tillers $\mathrm{m}^{-2}$, grains $\mathrm{ear}^{-1}$ and test weight than $I_{2}, I_{3}$ and $I_{4}$ due to late moisture supply to the crop and a trend for lesser productive tillers, grains spike ${ }^{-1}$ and test weight (compared to $I_{2}, I_{3}$ with $I_{4}$ ) but, trend not continued in case of $\mathrm{CRI}+50 \mathrm{~mm}\left(\mathrm{I}_{2}\right)$ compared with $\mathrm{CRI}+100 \mathrm{~mm}\left(\mathrm{I}_{3}\right)$ which were statistically at par (Table 1). Stimulated 
vegetative growth of wheat on account of adequate and prolonged supply of water in treatment manifested itself in increased productive tiller's, number of grains spike $^{-1}$, and test weight (Maurya and singh 2008; Naresh et al., 2013).

Yield components i.e. grain, straw and biological yield of wheat were also influenced by sowing techniques (Table 1). Crop yield under $\mathrm{T}_{4}$ FIRB and $\mathrm{T}_{1} \mathrm{ZT}$ were at par and significantly superior over other tillage crop establishment practices. However, $\mathrm{T}_{2}$ RT was significantly superior over remaining treatments. $\mathrm{T}_{3}$ and $\mathrm{T}_{5}$ were at par and lowest yield was obtained under $\mathrm{T}_{5}$ conventional tillage.

The higher grain yield in FIRB was mainly due to higher number of productive tiller's and number of grains spike ${ }^{-1}$ as compared with zero tillage. Bilalis et al., 2011 and Naresh et al., (2012) reported that the yield per hectare was primarily improved due to more moisture supply, less penetration resistance impedance which responsible for better root development and its beneficial effect on the per plant yield. The grain yield per plant improved with increased moisture supply mainly through improvement number of grains per spike, number of spikelet per spike and test weight.

The significant increase in number of effective tillers, number of grains per spike and test weight in $I_{2}$ over $I_{1}$ was observed during the experimentation. The more number of grains per spike were because of significant increase in spike length and number of spikelet per spike with subsequent increase in irrigation from $I_{1}$ to $I_{4}$ (Table 1). The harvest index per cent had shown no definite trend. However, treatments under $\mathrm{T}_{5}$ conventional tillage and $T_{3}$ rotavator tillage practices performed higher values of harvest index.

\section{Water productivity}

Water use efficiency (WUE) was similar to the tune of water applied in all irrigation treatments except $\mathrm{I}_{3}$ and $\mathrm{I}_{4}$ because assimilation and transpiration were affected approximately to the same degree by water stress. Water productivity of applied irrigation (WPI) and WPI+R (rainfall) increased with decrease in irrigation input. Table 2 also showed highest use efficiency under irrigation levels $\mathrm{I}_{3}$ CRI+100 $\mathrm{mm}$ and $\mathrm{I}_{4} \mathrm{CRI}+150 \mathrm{~mm}$. However, WUE was also different for treatments with the same irrigation amount but at different times, because grain production was affected by both the duration and the time of water stress. In less frequently irrigated treatments, a larger proportion of ET was supplied by residual soil moisture and rainfall, and thus WUE was less affected than WP (water productivity). Proper irrigation scheduled can be used to optimize crop yield at a given level of crop ET, leading to more yield per unit of ET. But, higher WP was of no value if associated with unacceptably low yield or unacceptably higher inputs. So it is necessary to schedule irrigations to develop a better and deeper root system to ensure that the crop extracts the maximum residual water from the soil profile, especially in wheat after rice where the subsoil contains a large amount of water.

\section{Changes in physical properties of soil}

\section{Bulk density}

Among tillage crop establishment methods, plots under zero tillage $\left(\mathrm{T}_{1}\right)$ had about $3.4 \%$ higher average soil bulk density than $\mathrm{T}_{4}$ plots the experimentation (Table 3). Tillage had greater impacts on soil bulk density. Plots under $\mathrm{T}_{2}$ and $\mathrm{T}_{5}$ had $\sim 3 \%$ less soil bulk density as compared with $\mathrm{T}_{1}$ treated plots (Table 3). The bulk density did varied significantly due to seeding techniques and it 
was significantly reduced under FIRB, reduced tillage and conventional tillage seeding techniques compared to zero tillage seeding. Similar findings were obtained by Jat et al., (2013); Naresh et al., (2013) suggests that wheat sown under no tillage was a viable and sustainable option over CT.

\section{Infiltration rate}

Among the various sowing techniques treatment $\mathrm{T}_{4}$ FIRB also recorded highest infiltration rate $\left(71.00 \mathrm{~mm} \mathrm{hr}^{-1}\right)$ was found significantly superior to all other treatments, except $\mathrm{T}_{2}$ during the experimentation (Table $3)$. The difference in infiltration rate due to tillage crop establishment treatments proved significant. Treatment $T_{2}$ was significantly superior to the remaining treatments. $\mathrm{T}_{5}$ was also significant over $T_{1}$ and $T_{3}$ treatment. However, $T_{1}$ recorded lowest infiltration rate
(50.00 $\mathrm{mm} \mathrm{ha}^{-1}$ ), respectively. This trend leads to indicate the water saving tendency of ZT seeding technique.

\section{Cone index (soil penetration resistance)}

The cone index (soil penetration resistance) increased with the decreased moisture supply and depth up to $15 \mathrm{~cm}$ and their after a decreasing trend were observed (Table 3). The crop retained more moisture i.e. tillage crop establishment treatments $\mathrm{T}_{2}$ reduced tillage and $\mathrm{T}_{4}$ FIRB recorded significantly lower soil penetration resistance as compared to $\mathrm{T}_{1}$ zero tillage and $\mathrm{T}_{3}$ rotavator tillage treatments. Similar findings were observed by Cavalaris and Gemtos (2002) revealed that cone indices had a general tendency to increase with soil depth regardless of tillage practices.

Table.1 Yield attributes and yields of wheat as influenced by tillage-cum-crop establishment methods and irrigation scheduling

\begin{tabular}{|c|c|c|c|c|c|c|}
\hline Treatments & $\begin{array}{l}\text { Productive } \\
\text { tillers }\left(\mathbf{m}^{-2}\right)\end{array}$ & $\begin{array}{l}\text { Grains } \\
\text { Spike }^{-1}\end{array}$ & $\begin{array}{c}\text { Test } \\
\text { weight }(\mathrm{g})\end{array}$ & $\begin{array}{c}\text { Grain } \\
\text { Yield }\left(\mathbf{q} \mathbf{h a}^{-1}\right)\end{array}$ & $\begin{array}{c}\text { Straw } \\
\text { yield } \\
\left(\mathbf{q} \mathbf{h a}^{-1}\right)\end{array}$ & $\begin{array}{c}\text { Harvest } \\
\text { Index }(\%)\end{array}$ \\
\hline \multicolumn{7}{|c|}{ Tillage crop establishment methods } \\
\hline $\mathrm{T}_{1} \mathrm{ZT}$ & 219 & 54 & 36.15 & 43.55 & 65.35 & 39.96 \\
\hline $\mathrm{T}_{2} \mathrm{RT}$ & 214 & 53 & 34.98 & 41.49 & 64.58 & 39.21 \\
\hline $\mathrm{T}_{3} \mathrm{ROT}$ & 212 & 53 & 34.77 & 39.29 & 60.29 & 39.61 \\
\hline $\mathrm{T}_{4} \mathrm{FIRB}$ & 224 & 55 & 36.41 & 44.57 & 66.40 & 40.26 \\
\hline $\mathrm{T}_{5} \mathrm{CT}$ & 210 & 53 & 34.66 & 38.98 & 58.96 & 39.94 \\
\hline$S E m \pm$ & 2.12 & 0.7 & 0.39 & 0.27 & 0.60 & 0.28 \\
\hline$C D P=0.05$ & 6.89 & 2.4 & 1.27 & 0.87 & 1.95 & 1.03 \\
\hline \multicolumn{7}{|c|}{ Irrigation schedule } \\
\hline $\mathrm{I}_{1} \mathrm{CRI}$ & 184 & 46 & 32.59 & 34.78 & 52.69 & 39.97 \\
\hline $\mathrm{I}_{2} \mathrm{CRI}+50 \mathrm{~mm}$ & 233 & 61 & 38.39 & 48.51 & 74.78 & 39.32 \\
\hline $\mathrm{I}_{3} \mathrm{CRI}+100 \mathrm{~mm}$ & 230 & 59 & 37.51 & 46.64 & 70.02 & 39.91 \\
\hline $\mathrm{I}_{4} \mathrm{CRI}+150 \mathrm{~mm}$ & 222 & 54 & 35.16 & 41.11 & 6310 & 39.45 \\
\hline $\mathrm{I}_{5} \mathrm{CRI}+200 \mathrm{~mm}$ & 210 & 48 & 33.30 & 36.85 & 54.98 & 40.34 \\
\hline$S E m \pm$ & 2.96 & 0.8 & 0.39 & 0.21 & 0.63 & 0.29 \\
\hline$C D P=0.05$ & 8.45 & 2.2 & 1.11 & 0.60 & 1.79 & 0.82 \\
\hline
\end{tabular}


Table.2 Effect of planting techniques and irrigation pattern on consumptive use $(\mathrm{cm})$ water use efficiency $\left(\mathrm{kg} \mathrm{m}^{-3}\right)$ and water productivity of soil in Wheat crop

\begin{tabular}{|c|c|c|c|}
\hline Treatments & $\begin{array}{c}\text { Consumptive } \\
\text { use }(\mathrm{cm})\end{array}$ & $\begin{array}{l}\text { Water use efficiency } \\
\left(\mathbf{q ~ h a} \mathbf{~ h m}^{-1} \mathbf{c m}\right.\end{array}$ & $\begin{array}{c}\text { Water productivity } \\
\left(\mathrm{kg} \text { grain } \mathrm{m}^{-3}\right)\end{array}$ \\
\hline \multicolumn{4}{|c|}{ Tillage crop establishment methods } \\
\hline $\mathrm{T}_{1} \mathrm{ZT}$ & 18.70 & 2.33 & 1.30 \\
\hline $\mathrm{T}_{2} \mathrm{RT}$ & 19.45 & 2.13 & 1.12 \\
\hline $\mathrm{T}_{3} \mathrm{ROT}$ & 22.50 & 1.75 & 0.98 \\
\hline $\mathrm{T}_{4}$ FIRB & 19.65 & 2.27 & 1.79 \\
\hline $\mathrm{T}_{5} \mathrm{CT}$ & 23.30 & 1.67 & 0.94 \\
\hline Mean & 20.72 & 2.03 & 1.22 \\
\hline \multicolumn{4}{|c|}{ Irrigation schedule } \\
\hline $\mathrm{I}_{1} \mathrm{CRI}$ & 12.55 & 2.80 & 2.90 \\
\hline $\mathrm{I}_{2} \mathrm{CRI}+50 \mathrm{~mm}$ & 26.95 & 1.80 & 0.82 \\
\hline $\mathrm{I}_{3} \mathrm{CRI}+100 \mathrm{~mm}$ & 21.95 & 2.12 & 1.00 \\
\hline $\mathrm{I}_{4} \mathrm{CRI}+150 \mathrm{~mm}$ & 18.00 & 2.28 & 1.15 \\
\hline $\mathrm{I}_{5} \mathrm{CRI}+200 \mathrm{~mm}$ & 14.55 & 2.55 & 1.55 \\
\hline Mean & 18.80 & 2.31 & 1.48 \\
\hline
\end{tabular}

Table.3 Effect of tillage crop establishment methods on bulk density of soil under Wheat cultivation

\begin{tabular}{|l|c|c|c|c|c|c|c|c|}
\hline \multirow{2}{*}{ Treatments } & \multicolumn{4}{|c|}{$\begin{array}{c}\text { Bulk Density } \\
\left(\mathbf{M g ~ m}^{-3}\right)\end{array}$} & \multicolumn{3}{c|}{$\begin{array}{c}\text { Soil Penetration } \\
\text { Resistance (M pa) }\end{array}$} & $\begin{array}{c}\text { Infiltration } \\
\text { Rate } \\
\end{array}$ \\
\cline { 2 - 8 } & $\mathbf{0 - 5} \mathbf{~ c m}$ & $\begin{array}{c}\mathbf{5 - 1 0} \\
\mathbf{c m}\end{array}$ & $\begin{array}{c}\mathbf{1 0 - 2 0} \\
\mathbf{c m}\end{array}$ & $\begin{array}{c}\mathbf{2 0 - 3 0} \\
\mathbf{c m}\end{array}$ & $\mathbf{0 - 5} \mathbf{~ c m}$ & $\mathbf{5 - 1 5} \mathbf{~ c m}$ & $\mathbf{1 5 - 3 0} \mathbf{~ c m}$ & \\
\hline $\mathrm{T}_{1}(\mathrm{ZT})$ & 1.43 & 1.50 & 1.59 & 1.62 & 1.95 & 3.91 & 3.06 & 50.00 \\
\hline $\mathrm{T}_{2}(\mathrm{RT})$ & 1.40 & 1.48 & 1.58 & 1.63 & 1.06 & 2.62 & 2.17 & 67.00 \\
\hline $\mathrm{T}_{3}(\mathrm{ROT})$ & 1.38 & 1.47 & 1.59 & 1.66 & 1.57 & 3.52 & 2.97 & 54.50 \\
\hline $\mathrm{T}_{4}(\mathrm{FIRB})$ & 1.34 & 1.44 & 1.54 & 1.62 & 1.27 & 3.16 & 3.31 & 71.00 \\
\hline $\mathrm{T}_{5}(\mathrm{CT})$ & 1.37 & 1.46 & 1.57 & 1.65 & 1.58 & 3.85 & 3.40 & 60.00 \\
\hline$S E(m \pm)$ & 0.02 & 0.03 & 0.04 & 0.04 & 0.02 & 0.03 & 0.03 & 2.81 \\
\hline$C D(P=0.05)$ & 0.05 & 0.07 & 0.16 & 0.17 & 0.07 & 0.08 & 0.09 & 9.34 \\
\hline
\end{tabular}


Table.4 Effect of crop establishment methods and irrigation scheduling on profitability

\begin{tabular}{|l|c|c|c|c|}
\hline Treatments & $\begin{array}{c}\text { Cost of Cultivation } \\
\left(\text { Rs ha }^{-1}\right)\end{array}$ & $\begin{array}{c}\text { Gross income } \\
\left(\text { Rs ha }^{-1}\right)\end{array}$ & $\begin{array}{c}\text { Net return } \\
\left(\text { Rs ha }^{-1}\right)\end{array}$ & B:C ratio \\
\hline \multicolumn{5}{|c|}{ Tillage crop establishment practices } \\
\hline $\mathrm{T}_{1}-\mathrm{ZT}$ & 28330 & 64989 & 36659 & 1.29 \\
\hline $\mathrm{T}_{2}-\mathrm{RT}$ & 28802 & 60739 & 31937 & 1.11 \\
\hline $\mathrm{T}_{3}-\mathrm{ROT}$ & 29305 & 57586 & 28281 & 0.96 \\
\hline $\mathrm{T}_{4}-\mathrm{FIRB}$ & 30637 & 67080 & 36443 & 1.19 \\
\hline $\mathrm{T}_{5}-\mathrm{CT}$ & 32115 & 56696 & 24581 & 0.76 \\
\hline \multicolumn{5}{|c|}{ Irrigation schedule } \\
\hline $\mathrm{I}_{1}-\mathrm{CRI}$ & 28344 & 41286 & 12942 & 0.46 \\
\hline $\mathrm{I}_{2}-\mathrm{CRI}+50 \mathrm{~mm} \mathrm{CPE}$ & 33393 & 77961 & 44569 & 1.33 \\
\hline $\mathrm{I}_{3}-\mathrm{CRI}+100 \mathrm{~mm}$ CPE & 29605 & 75511 & 45906 & 1.55 \\
\hline $\mathrm{I}_{4}-\mathrm{CRI}+150 \mathrm{~mm} \mathrm{CPE}$ & 29238 & 62731 & 33493 & 1.14 \\
\hline $\mathrm{I}_{5}-\mathrm{CRI}+200 \mathrm{~mm} \mathrm{CPE}$ & 28612 & 49573 & 20962 & 0.73 \\
\hline
\end{tabular}

Treatments $\mathrm{T}_{1}$ zero tillage wheat under (ZTDSR and ZT wheat system) had significantly higher bulk density as well as soil penetration resistance in the $0-5$ and $5-10 \mathrm{~cm}$ soil profile as compared to conventional tillage systems (rice under conventional puddled and wheat by conventional tillage practice),However, under $10-15$ and $15-20-\mathrm{cm}$ soil layers bulk density and soil penetration resistance were higher in $\mathrm{T}_{5}$ conventional-tillage as compared to treatment $\mathrm{T}_{1}$ zero tillage sown wheat (Jat et al., 2009). The linear trend line was much steeper for no-tillage than conventional tillage, meaning that $\mathrm{CI}$ of no-till soil increased more rapidly with depth (0-200 $\mathrm{mm}$ ) than that of conventionally tilled soil. These results are in conformity with those reported earlier by Yang et al., (1999), Jat et al., (2009) and Govaerts et al., (2009).

\section{Profitability}

It was observed that sowing of wheat under FIRB was more beneficial than CT for improving productivity and profitability (pooled data of 2014-15 and 2015-16 in table 4). ZT and RT stands closely to FIRB in terms of B: C ratio. Similarly, though CRI+50 $\mathrm{mm}$ recorded maximum gross income whereas, CRI+100 $\mathrm{mm}$ result in higher net return as well as $\mathrm{B}$ : $\mathrm{C}$ ratio. Irrigation scheduled at $\mathrm{I}_{4} \mathrm{CRI}+150 \mathrm{~mm}$ was considered as viable option where irrigation water is a scarce resource. However, $\mathrm{I}_{1}$ and $\mathrm{I}_{5}$ could not shown beneficial result for wheat cultivation. Moreover, wheat was grown successfully under ZT condition as the productivity was nearly similar but, profitability was highest compared with other planting techniques. Although FIRB resulted in higher cost, this practice was particularly beneficial under intensive cropping system and might result in increasing food security. Among the irrigation practices, the maximum mean gross income (Rs. $77961 \mathrm{ha}^{-1}$ ), and net income (Rs.45906ha ${ }^{1}$ ) and benefit: cost ratio (1.55) was recorded with irrigation levels $I_{2}$ followed $I_{3}$ during experimentation. This might be due to higher productivity of the wheat crop. These results are in conformity with the findings of Gathala et al., 2011; Jat et al., 2013; and Naresh et al., 2015.

In conclusion the study indicated an improvement in yield attributes and yield of wheat under FIRBS as compared to other 
method of planting. In case of irrigation schedules, irrigation at $\mathrm{I}_{2} \mathrm{CRI}+50 \mathrm{~mm} \mathrm{CPE}$ (five irrigations) and under $\mathrm{ZT}$ seeding system and irrigation at $\mathrm{I}_{3} \mathrm{CRI}+100 \mathrm{~mm} \mathrm{CPE}$ (three irrigations) gave higher yield as compared to other irrigation schedules in subtropical climatic conditions of northern India i.e. western Uttar Pradesh condition. The same reason could be ascribed to this as well.

\section{Acknowledgement}

This study has been executed at the Crop research centre of Sardar Vallabhbhai Patel University of Agriculture and Technology, Meerut, Uttar Pradesh, India under the Department of Agronomy between 2014-15 and 2015-16. I would like to thank the Department of Agronomy for offering me the necessary facilities during this period.

\section{References}

Bilalis, Dimitrios, Karkanis, Anestis, Patsiali, Sotiria, Agriogianni, Maria, Aristeidis, Konstantas and Vassilios Triantafyllidis. 2011. Performance of wheat varieties (Triticum aestivum L.) under conservation tillage practices in organic agriculture. Notulae Botanicae Horti Agro botanici, 39(2): 28-33

Blanco-Canqui, H. and Lal, R. 2007.Impacts of long-term wheat straw management on soil hydraulic properties under notillage. Soil Sci. Soc. Am. J., 71: 11661173.

Campbell, G.S. and Cambell, M.D. 1982. Irrigation scheduling using soil moisture measurements: Theory and practice. (In) Advances in Irrigation, Vol $1, \mathrm{pp}$ 25-42. Hillel D (Ed). Academic Press, New York.

Cavalaris, C.K. and Gemtos, T.A. 2002. Evaluation of four conservation tillage methods in the Sugar Beet Crop. Agri.
Engi. Int. the CIGR J. Scientific Res. Develop., 4(6): 24-29.

Gathala, M., Ladha, J.K., Balyan, V., Saharawat, Y.S., Kumar, V., Sharma, P.K. 2011. Effect of tillage and crop establishment methods on physical properties of a medium-textured soil under 7-year rice-wheat rotation. Soil Sci. Soc. American J., 75: 1-12.

Govaerts, B., Sayre, K.D., Goudeseune, B., De Corte, P., Lichter, K., Dendooven, L., Deckers, J. 2009. Conservation agriculture as a sustainable option for the central Mexican highlands. Soil and Tillage Res., 103: 222-230.

Govaerts, B., Sayre, K.D., Lichter, K., Dendooven, L. and Deckers, J. 2007. Influence of Permanent Raised Bed Planting and Residue Management on Physical and Chemical Soil Quality in Rainfed Maize/Wheat Systems. Plant Soil, 291(1-2): 39-54.

Hill, J.E., Bayer, D.E., Bocchi, S. and Clampett, W.S. 1991. Direct Seeded Rice in the Temperate Climates of Australia," Direct Seeded Flooded Rice in the Tropics, IRRI, Manila, pp. 91102.

Jat, M.L., Gathala, M.K., Ladha J.K., Sahrawat, Y.S., Jat, A.S., Sharma, S.K., Kumar, V., Gupta, R.K. 2009. Evaluation of precision land levelling and double zero-till systems in the ricewheat rotation: water use, productivity, profitability and soil physical properties. Soil Tillage Res., 105(1): 112-121.

Jat, M.L., Gathala, M.K., Saharawat, Y.S., Tetarwale, J.P., Gupta, Raj and Singh Yadvinder. 2013. Double no-till and permanent raised beds in maize-wheat rotation of north-western Indo-Gangetic plains of India: Effects on crop yields, water productivity, profitability and soil physical properties. Field Crops Res., 149: 291-299. 
Jat, M.L., Singh, S., Rai, H.K., Chhonkar, R.S., Sharma, S.K. and Gupta, R.K. 2005. Furrow Irrigated Raised Bed Planting Technique for Diversification of Rice-Wheat System of Indo-Gangetic Plains. J. Japan Association for Int. Cooperation Agric. Forest, 28: 25-42.

Ladha, J.K., Kumar, V., Alam, M.M., Sharma, S., Gathala, M.K., Chandna, P., Saharawat, Y.S., Balasubramanian, V. 2009. Integrating crop and resource management technologies for enhanced productivity, profitability and sustainability of the rice-wheat system in South Asia. Integrated Crop and Resource Management in the RiceWheat System of South Asia, 69-108.

Ladha, J.K., Pathak, H., Padre, A.T., Dawe, D. and Gupta, R.K. 2003. Productivity trends in intensive rice-wheat cropping systems in Asia", In: J.K. Ladha, et al., Eds., Improving the Productivity and Sustainability of Rice-Wheat Systems: Issues and Impacts, ASA Spec. Publ. 65, ASA, CSSA and SSSA, Madison, pp. 45-76.

Maurya, R.K., Singh, G.R. 2008. Effect of crop establishment methods and irrigation schedules on economics of wheat (Triticum aestivum) production, moisture depletion pattern, consumptive use and crop water-use efficiency. Indian J. Agri. Sci., 78 (10): 830-833.

Monsefia, A., Sharma, A. R. and Zan, Rang, N. 2016. Weed management and conservation tillage for improving productivity, nutrient uptake and profitability of wheat in soybean (Glycine max)-wheat (Triticum aestivum) cropping system. Int. J. Plant Production, 10(1): 1-12.

Naresh, R.K., Singh, S.P. and Kumar. V. 2013. Crop establishment, tillage and water management technologies on crop and water Productivity in the rice-wheat cropping system of North West-India.
Int. J. Life Sci. Bt. Pharm. Res., 2(3): 237-248.

Naresh, R.K., Singh, S.P., Singh, A., Kamal, Khilari, Shahi, U.P. and Rathore, R.S. 2012. Evaluation of precision land leveling and permanent raised bed planting in maize-wheat rotation: productivity, profitability, input use efficiency and soil physical properties. Indian J. Agri. Sci., 105(1): 112-121.

Naresh, R.K., Prem Singh, Purushottam, Shahi, U.P., Singh, S.P. and Gupta, Raj K. 2015. Management of crop residues in rice-wheat cropping system on crop productivity and soil properties through conservation effective tillage in north western India. J Farming Systems Res. Develop., 21(1): 27-38

Piper, C.S. 1966. Soil and Plant Analysis. Hans Publishers, Bombay, India.

Prihar, S.S. and Sandhu, B.S. 1987. Irrigation of Field Crops - Principles and Practices. Indian Council of Agricultural Research (ICAR), New Delhi.

Prihar, S.S., Gajri, P.R. and Narang, R.S. 1974. Scheduling irrigation to wheat using open pan evaporation. Indian $J$. Agri. Sci., 44: 567-71.

Rajaram, S., Sayre, K.D., Diekmann, J., Gupta, R.K. and Erskine, W. 2007. Sustainability Considerations in Wheat Improvement and Production. In: M. S. Kang, Ed., Agricultural and Environmental SustainabilityConsiderations for Future, Haworth Food \& Agricultural Products Press, New York, pp. 105-124.

Reynolds, M.P., Trethowan, R., Crossa, J., Vargas, M. and Sayre, K.D. 2004. Physiological factors associated with genotype by environment interaction in wheat. Field Crops Res., 85: 253-274.

Rodell, M., Velicogna, I. and Famiglietti, J.S. 2009. Satellite-based estimates of groundwater depletion in India. Nature, 
460: 999-1002.

Saharawat, Y.S., Bhagat, S., Malik, R.K., Ladha, J.K., Gathala, M.K., Jat, M.L. and Kumar, V. 2010. Evaluation of Alternative Tillage and Crop Establishment Methods in a Rice-Wheat Rotation in North Western IGP. Field Crop Res., 116(3): 260-267.

Sayre, K.D. 2004. Raised Bed Cultivation. In: R.Lal, Ed., Encyclopedia of Soil Science, Marcel Dekker, Inc., New York.
Shaver, T.M., Peterson, G.A., Ahuja, L.R., Westfall, D.G., Sherrod, L.A. and Dunn, G. 2002. Surface soil physical properties after twelve years of dry land no-till management. Soil Sci. Soc. Am. J., 66(4): 296-1303.

Yang, Y.S., He, Z.M., Chen, G.S., Chen, Y.B. 1999. A study on lateritic red soil antierodibility under different biological treatments. Acta Pedologica Sinica, 4: $52-58$.

\section{How to cite this article:}

Vikrant Singh, R.K. Naresh, Ravindra Kumar, Adesh Singh, U. P. Shahi, Vivak Kumar and Rana, N.S. 2017. Enhancing Yield and Water Productivity of Wheat (Triticum aestivum) Through Sowing Methods and Irrigation Schedules under Light Textured Soil of Western Uttar Pradesh. Int.J.Curr.Microbiol.App.Sci. 6(4): 1400-1411. doi: https://doi.org/10.20546/ijcmas.2017.604.171 